\title{
POLITIK PENDIDIKAN JEPANG DAN PENGARUHNYA TERHADAP PENDIDIKAN ISLAM DI INDONESIA
}

\author{
M. Syarif \\ Fakultas Agama Islam Universitas Islam Majapahit Mojokerto \\ Email : gilangcempaka78@gmail.com
}

\begin{abstract}
Abstrak
Kajian ini membicarakan kebijakan pendidikan pemerintah penjajajahan Jepang serta pengaruhnya terhadap eksistensi pendidikan Islam di Indonesia. Fokus perbincangannya meliputi kebijakan politik secar umum pemerintah Jepang terhadap Islam di Indonesia, kebijakan pendidikan Jepang yang terkait dengan pendidikan Islam Indonesia, sistem pendidikan yang dibangun di masa pemerintahan Jepang, dan dampaknya terhadap pendidikan Islam di Indonesia saat itu. Secara konseptual, penjajahan Jepang yang berlangsung selama rentang waktu tiga setengah tahun sejak 1942 sampai 1945 telah melahirkan banyak perubahan terhadap sistem dan dinamika pendidikan Indonesia yang memiliki efek jangka panjang hingga pada masa Indonesia merdeka. Polemik yang muncul adalah apakah kebijakan pendidikan pemerintah Jepang tersebut lebih banyak memberikan ekses positif atau negatif terhadap pendidikan di Indonesia termasuk terutama pendidikan Islam di Indonesia.
\end{abstract}

Keyword : Kebijakan Pendidikan, Zaman Jepang, Pendidikan Islam

\section{PENDAHULUAN}

Kajian terhadap dinamika pendidikan di Indonesia zaman Jepang hingga dewasa ini belum banyak dilakukan. Halaman-halaman literatur sejarah pendidikan di Indonesia rata-rata menyediakan lembaran yang sangat sedikit dalam memaparkannya. Lebih-lebih bila kajian tersebut dikhususkan pada pengaruhnya terhadap eksistensi pendidikan Islam, akan tampak lebih jarang lagi. Padahal masa tiga setengah tahun penjajajahan Jepang di Indonesia, yaitu sejak 1942 hingga pertengahan 1945, telah memberikan pengaruh yang sangat penting dan menentukan bila dilihat dari dampak jangka panjangnya terhadap sistem pendidikan di Indonesia sesudahnya. ${ }^{1}$

1 Literatur mengenai sejarah Pendidikan Islam Indonesia umumnya hanya memberikan porsi yang sedikit untuk memperbincangkan situasi dan kondisinya di era Jepang, apalagi mengenai pengaruh kebijakan Jepang terhadapnya. Bahkan, kGUnawaa yang selama ini dijadikan buku rujukan utama mengenai sejarah pendidikan Islam Indonesia yang ditulis oleh Mahmud Yunus hanya memberikan porsi tiga hlmaman untuk membahas pendidikan Islam 
Pergantian kekuasaan dari pemerintahan kolonial Belanda kepada pemerintahan pendudukan Jepang banyak memberikan perubahan wajah pendidikan Indonesia. Anehnya, rata-rata literature sejarah pendidikan hanya bercerita mengenai bagaimana sulit dan mundurnya kondisi pendidikan pada zaman itu, di mana aktivitas pendidikan ditujukan untuk kepentingan Jepang sebagai wadah indoktrinasi ideologi dan budaya Jepang kedalam proses pembelajaran. Sementara di sisi lain, Jepang juga menggunakan rakyat untuk dijadikan pekerja paksa (Romusha) guna mengeksploitasi kekayaan alam Indonesia demi kepentingan perang Jepang.

Meskipun begitu, sesungguhnya, tidak seluruh kebijakan Jepang bernilai negatif terhadap pendidikan Indonesia. Sebagai perbandingan, jika dalam pemerintahan Belanda sistem pendidikan di belah menjadi dua, dan jenis-jenis sekolah Belanda begitu beragam, di era Jepang semuanya dihapus dan diseragamkan. Pola ini tetap digunakan oleh pemerintah Indonesia di masa kemerdekaan. Jepang juga mengupayakan sebuah sistem pendidikan di Indonesia yang lebih egaliter, yang tidak membeda-bedakan lagi kelas sosial ditengah rakyat Indonesia di mana semua rakyat bisa menikmati pendidikan sesuai yang mereka kehendaki.

Kajian ini memfokuskan perbincangan pada polemik sistem pendidikan era Jepang tersebut. Di sini, penulis hanya membatasi pembahasan pada kebijakan Jepang dalam bidang pendidikan sebagai unsur dasar yang membangun sistem di atas, kaitannya dengan dampak yang ditimbulkan terhadap eksistensi pendidikan Islam di Indonesia. Kebijakan-kebijakan bidang pendidikan itu akan dikaji lebih mendalam melalui penelusuran ke sejumlah literatur sejarah baik sejarah yang terkait politik pendidikan maupun sejarah kebijakan pendidikan di Indonesia. Kebijakan sosial politik juga akan disinggung sejauh terkait dengan pembicaraan pokoknya, yaitu pendidikan. Dalam konteks ini, kebijakan politik dan kebijakan pendidikan pemerintah Jepang memiliki pengaruh yang saling terkait dengan dinamika pendidikan Indonesia, itu sebabnya maka

zaman penjajahan Jepang. Memang terdapat bahasan mengenai Madrasah Awwaliyah yang lahir di era Jepang dalam buku ini, tetapi itupun tak dikaitkan sebagai pengaruh dari kebijakan Jepang atas lahirnya model madrasah tersebut. Lihat, Mahmud Yunus, Sejarah Pendidikan Islam Indonesia, (Jakarta, Mutiara Sumber Widya, 1962),hlm. 121-123. Satu-satunya karya komprehensif yang membicarakan tentang era penjajahan Jepang dan persentuhannya dengan Islam Indonesia adalah hasil penelitian yang dilakukan oleh Harry J. Benda, Bulan Sabit dan Matahari Terbit : Islam Indonesia pada Masa Pejajajahan Jepang, (Jakarta, Pustaka Jaya, 1980 Tetapi karya sejarah fenomenal ini tidaklah secara khusus berbincang tentang pendidikan Islam di Indonesia zaman Jepang, melainkan tentang pergulaan politik Islam di era penjajahan Jepang. Meski begitu, dalam banyak konteks karya ini sangat berharga untuk "sekedar menelusuri" jejak adanya pengaruh kebijakan politik Jepang terhadap pendidikan dimaksud. Satu karya langka lagi yang patut disebut di sini adalah karya Soegarda Porbakawatja, Pendidikan dalam Alam Indonesia Merdeka, (Jakarta, Gunung Agung, 1970). 
pembahasan yang akan dilakukan dibawah dibagi pada dua hal yaitu kebijakan politik Jepang dan Kebijakan Pendidikan Jepang. Beberapa pertanyaan berikut akan dijadikan sebagai dasar pembahasan ; (1) Bagaimana kebijakan politik pemerintah Jepang terhadap umat Islam, (2) Bagaimana kebijakan politik pendidikan pemerintah Jepang yang terkait dengan pendidikan Islam, (3) Bagaimana kondisi sistem pendidikan Indonesia pada umumnya di zaman pemerintah Jepang. Bertitik tolak dari empat dasar pembahasan itulah nantinya akan disimpulkan pengaruh kebjakan politik pendidikan Jepang terhadap pendidikan Islam di Indonesia.

Kajian ini dimaksudkan untuk mendapatkan pengetahuan yang lebih mendalam dan komprehensif mengenai era singkat penjajahan negeri matahari terbit ini dalam hlm kebijakan pendidikannya di Indonesia. Kajian ini bersifat kajian literatur di mana sebagain besar data yang dipaparkan diperoleh dari buku-buku khususnya yang berbicara mengenai sejarah pendidikan Islam dan pergulatan politik Islam di zaman Jepang. Diharapkan, wawasan lebih luas mengenai politik pendidikan zaman Jepang ini pada gilirannya akan semakin memperkaya khazanah pemikiran sejarah politik pendidikan di Indonesia.

\section{KEBIJAKAN POLITIK JEPANG TERHADAP UMAT ISLAM}

Di awal abad ke 20 bangsa Jepang tampil sebagai negara kuat dari Asia. Ketika dunia dilanda perang dunia II, Jepang ikut andil dalam perang tersebut dengan sekian banyak prestasi termasuk mengalahkan Rusia. Jepang bercita-cita menjadi pemimpin Asia Timur Raya. Belanda yang sekian lama menjajah Indonesia dapat dikalahkan oleh Jepang. Sehingga akhirnya kekuasaan beralih dari pemerintah Kolonial Belanda kepada Jepang. ${ }^{2}$

Awal terjadinya penjajahan Jepang di Indonesia dimulai pada saat Jepang melakukan penaklukan Asia Tenggara sejak tahun 1941. Mulanya, sebuah faksi perlawanan yang ada di Aceh mendapatkan bantuan dari pasukan Jepang untuk menghadapi Belanda. Faksi ini, seiring dengan perjuangan rakyat Aceh yang sekian lama melawan penjajahan, telah menjadi jalan masuk Jepang untuk melancarkan rencana revolusi mengusir pemerintahan Belanda. Dari sini dapat dikatakan bahwa

2 Muhammad Rifa'i, Sejarah Pendidikan Nasional, (Yogyakarta: Ar-ruzz Media, 2011),hlm. 
hubungan Jepang-Islam sesungguhnya telah dibangun jauh sebelum Islam menjajah Indonesia melalui bantuan militer.

Satu tahun setelahnya, pihak Jepang mengarahkan pasukannya ke Jawa. Pada 1 Maret 1942, pasukan Jepang mencapai pantai Banten dan bergerak dengan cepat ke Batavia yang dinyatakan oleh Belanda sebagai kota terbuka. Batavia diduduki pada 5 Maret 1942 dan tiga hari kemudian pada 9 Maret 1942 Gubernur Jenderal Hindia Belanda, Mr. Jhr. Tjarda Van Stakenborg Stachouwer menyerah tanpa syarat kepada Letnan Jenderal; Hitoshi Imamura, komandan Tentara ke XVI Jepang yang bergerak ke wilayah Indonesia. ${ }^{3}$ Segera sesudahnya Jepang menguasai seluruh pulau Jawa dan menghabisi seluruh sisa pasukan Belanda. Dengan demikian era penjajahan Jepang atas Indonesia dimulai.

Tatkala datang pertama kali ke Indonesia, umat Islam menyambut baik kedatangan Jepang dan mengakui arti penting mereka, sebuah penghargaan yang tidak ada selama masa-masa penjajahan Belanda. Jepang sendiri, dalam kaitannya dengan Islam, sudah siap sejak pertengahan 1930-an untuk memposisikan diri sebagai pelindung Islam di Asia. Mereka datang dengan gagasan bahwa kalangan Islam Indonesia adalah aliansi potensial yang akan menyambut mereka sebagai pembebas Asia. Sedangkan kelompok nasionalis, yang lebih dipengaruhi oleh pendidikan Barat (Belanda) dan sudah menyatakan dukungan kepada sekutu, jelas tidak dapat mereka percayai. ${ }^{4}$ Apa yang dimaksud sekutu adalah aliansi militer Amerika, Inggris, Uni Sovyet, dan Tiongkok dalam perang dunia ke 2 .

Pada akhir 1942, seiring dengan pemikiran tentang peran penting Islam dalam kehidupan sosial masyarakat Indonesia, Jepang membentuk kantor urusan agama yang bernama Shumubu. Kantor ini sekaligus menggantikan kantor serupa yang telah ada pada era belanda, "Kantoor Voor Inlandsche Zaken". ${ }^{5}$ Shumubu, pada era

3 Lihat, Abdul Qadir Djaleani, Sejarah Gerakan Politik Umat Islam Indonesia, (Jakarta, Bee Media, 2016), hlm. 515-516. Buku setebal seribu hlmaman lebih ini, kendatipun tidak sistematis dalam pembahasannya, tetapi cukup bisa dijadikan bandingan untuk membaca tentang sumbangsih dan peranan umat Islam dalam gerakan politik Indonesia termasuk di bidang politik pendidikan dengan referensi yang relatif kaya

4 Robert Pringle, Islam Ditengah Kebhinnekaan, Memahami Islam dan Politik di Indonesia, (Jakarta, Prenada, 2018), hlm. 51. Kedekatan Jepang dengan Islam ini berlangsung sampai masa-masa akhir penjajahan mereka kendatipun pada periode pertengahannya sempat muncul ketegangan hubungan terkait dengan ketidaksetujuan kalangan Islam pada beberapa usaha Jepang untuk menanamkan ideology dan budaya Nippon, baik melalui jalur pendidikan maupun organisasi, yang oleh umat Islam, dinilai mengabaikan sisi keagamaan yang paling utama, Aqidah.

5 Kantoor Voor Inlandsche Zaken yang berfungsi sebagai kantor penasehat untuk masalah pribumi. Dan karena sebagian besar pribumi itu beragama Islam, maka dengan sendirinya 
penjajahan Jepang berfungsi sebagai penasehat umum dalam masalah agama yang antara lain bertugas mengangkat pegawai agama dan mengawasi buku-buku agama. ${ }^{6}$ Dan terkait dengan Masyumi diatas, setiap kiyai dan ulama secara pribadi dapat menjadi anggota Masyumi dengan persetujuan Shumubu. ${ }^{7}$

Berbeda dengan pemerintah kolonial Belanda, Shumubu sebagai kantor urusan agama yang dibentuk oleh pemerintah kolonial juga, merupakan kantor pertama yang anggota-anggotanya diisi oleh orang-orang pribumi dan diketuai oleh orang pribumi. ${ }^{8}$ Pertama kali, sebagai pimpinannya, Jepang mengangkat K.H Hasyim Asy'ari, seorang ulama berpengaruh di tanah Jawa. Pada masa Jepang, kantor ini telah mempunyai cabang hampir diseluruh kota keresidenan (kabupaten di masa sekarang). dan berpusat di Jakarta. ${ }^{9}$

Di tangan para ulama ini, Shumubu memiliki peran yang fungsional bagi perkembangan pendidikan Islam. Pada 1944, Kepala kantor Shumubu di Keresidenan Banyumas mengusulkan supaya diberikan pendidikan agama di seluruh sekolah desa yang ada di keresidenannya. Usul ini disetujui oleh kantor Shumubu pusat di Jakarta. Tetapi gaji para guru agama tersebut diberi oleh Pemerintah Daerah setempat. Persetujuan yang sama juga diberikan pada keresidenan lain seperti Kediri dan Pekalongan. Dalam hal ini, dapat dikatakan bahwa garis kebijakan pendidikan agama

masalah Islam menjadi bidang garapan utama kantor ini Lihat, Aqib Suminto, Politik Islam Hindia Belanda, (Jakarta, LP3ES, 1984), hlm. 110

${ }^{6}$ Selain Shumubu, Jepang juga membentuk sebuah lembaga dewan penasehat pemerintah bernama Chuo Sangiin untuk pusat dan Chuo Sangi Kai untuk daerah. Lembaga dewan penasehat ini dididikan untuk menggantikan Volksraad sebagai dewan penasehat pemerintah zaman Belanda. Meskipun lembaga baru ini sesungguhnya tak berdaya jika dibanding peran Volksraad, tetapi keterwakilan umat Islam menjadi lebih banyak daripada sebelumnya yang semula hanya diisi oleh 1 orang, di era Jepang menjadi 6 orang sebagai perwakilan pihak Islam dari total 43 orang anggota dewan. Tetapi bagi umat Islam, kondisi ini sesungguhnya tidak representatif bila mengingat bahwa rakyat Indonesia kebanyakan muslim. Di Chuo Sangiin, sebanyak 37 orang anggotanya (dari total 43) berasal dari kalangan nasionalis, priyayi, dan Kristen. Oleh karena itu bagi umat Islam, peran lembaga ini sangat kecil artinya untuk memperjuangkan kepentingan mereka jika dibanding Shumubu yang dipandegani sebagian besar oleh kalangan Islam. Lihat, Pringle, Islam, hlm. 51. Djaelani, Sejarah, hlm 525

7 Benda, Bulan Sabit, hlm. 186-187

8 Lihat, Steenbrink, Pesantren, Madrasah, Sekolah ; Pendidikan Islam dalam Kurun Modern, (Jakarta, LP3ES, 1994), hlm. 85. Aneh juga bahwa, dalam hasil penelitiannya mengenai pendidikan Islam Indonesia ini, Steenbrink sangat sedikit membahas perihlm peran Shumubu ini beserta kebijakan pemerintah Jepang lainnya dalam konteks pengaruhnya terhadap dinamika pendidikan Islam di Indonesia. Ini juga menimbulkan kecurigaan bahwa di sana memang ada sisi sejarah yang ingin ditutupi mengenai peran penting Jepang dalam konteks terkait.

9 Steenbrink, Pesantren, hlm. 85-86 
telah mendapatkan benih kebijakan yang positif dan dukungan justru sejak era pemerintahan Jepang. ${ }^{10}$

Dari sana kita bisa membandingkan, jika pada masa kolonial Belanda, sekolah umum tidak diperkenankan memasukkan pelajaran agama Islam sebagai mata pelajaran dengan alasan pengajaran di sekolah umum itu bersifat netral. Pelajaran agama hanya boleh diberikan di luar jam belajar sekolah. Kondisi ini berlanjut hingga akhir pemerintahan Belanda. Kondisi ini berbeda pada era pemerintahan Jepang dengan diperbolehkannya pendidikan agama di sekolah umum sebagai efek dari ditiadakannya diskriminasi menurut golongan penduduk, keturunan, dan agama sehingga semua lapisan masyarakat mendapat kesempatan yang sama dalam bidang pendidikan. ${ }^{11}$ meskipun guru agama tidak digaji oleh pemerintah Jepang melainkan oleh pemerintah daerah.. Dalam hal ini, Shumubu memiliki peran penting yang membangun jembatan penghubung untuk menyalurkan aspirasi umat Islam dan mempersuasi kebijakan pemerintah Jepang agar dikabulkan. ${ }^{12}$

\section{KEBIJAKAN PENDIDIKAN JEPANG TERKAIT PENDIDIKAN ISLAM}

Berbeda dengan kedatangan Belanda ke Indonesia yang dilandasi motif perdagangan dan misi kristenisasi, Jepang datang pertama kali ke Indonesia murni dengan motif politik militer yang memiliki tujuan sejajar dengan ideologi imperialisme dunia pada umumnya. Motif ini jelas mempengaruhi kebijakan yang diberlakukan kemudian oleh masing-masing bangsa penjajah itu. Dalam era Belanda, kebijakan pendidikan diarahkan untuk mendukung upaya Kristenisasi. ${ }^{13}$ Sedangkan di era penjajahan Jepang, pendidikan diarahkan untuk mendukung Jepang guna memenangkan pertempuran dan memperkokoh eksistensinya di Indonesia. ${ }^{14}$

10 Ibid, hlm. 87

11 Ary H. Gunawan, Kebijakan-kebijakan Pendidikan, ( Jakarta, Rineka Cipta,1 995), hlm.

12 Meskipun demikian patut diketahui bahwa Selama periode Belanda dan Jepang, pendidikan Islam diorganisasikan oleh umat Islam sendiri melalui pendirian madrasahmadrasahnya yang tersebar di pedesaan. Pengorganisasian madrasah sebagai bagian dari sistem pendidikan nasional yang dimasukkan kedalam undang-undang secara resmi baru dilakukan seteah Indonesia merdeka

13 Lihat, Soegarda Poerbakawatja, Pendidikan dalam Alam Indonesia Merdeka, (Jakarta,, Gunung Agung, 1970), hlm. 33

14 Dengan latar belakang itupula dapat disadari mengapa Jepang tidak mengambil posisi berseberangan dengan kalangan Islam dalam kebijakan politiknya pada awal-awalnya. Usaha memenangkan perang berarti pula usaha untuk sebanyak mungkin membangun aliansi. Dan dalam hlm ini, umat Islam bisa diajak bergandeng tangan untuk memerangi pasukan sekutu yang 
Misi khusus dari kebijakan pendidikannya adalah menipponkan bangsa dan umat Islam di Indonesia, dalam arti pengalihan budaya kelndonesiaan ke akar budaya Jepang. Pola ini disebut sebagai Politik Nipponisasi. Politik ini juga pernah dilakukan Jepang pada Manchuria, Korea dan Taiwan sebelum Perang Dunia II. ${ }^{15}$

Dalam kontek ini patut dicatat bahwa pemerintah Jepang di masa pendudukannya telah menutup semua sekolah warisan Belanda dan menggantinya dengan sekolah-sekolah baru yang diseragamkan untuk seluruh rakyat Indonesia. Tetapi kebijakan ini tidak diberlakukan terhadap pesantren dan madrasah. Dua lembaga pendidikan berciri khas Islam ini beruntung karena dibebaskan dari pengawasan Jepang sehingga membuka kemungkinan keduanya untuk tetap berjalan dan berkembang dengan wajar. ${ }^{16}$.

Kebijakan itu bisa dimaklumi sebagai usaha untuk meraih simpati umat Islam. Dan dalam rangka meraih simpati umat Islam pula Jepang banyak melakukan kunjungan ke pesantren-pesantren besar. ${ }^{17}$ Secara historis, keberadaan pesantren telah dikenali sebagai pusat pendidikan tradisional umat Islam di Indonesia yang sewaktu-waktu juga berfungsi sebagai rahim bagi ideologi pemberontakan melawan Belanda. ${ }^{18}$ Dalam konteks ini, kunjungan Jepang ke pesantren -sebagaimana kebijakan untuk tidak menutup madrasah- adalah dimaksudkan sebagai langkah pendekatan guna meyakinkan kalangan Islam guna mengambil simpati mereka dengan melakukan politik pencitraan bahwa pemerintah Jepang memiliki kepedulian terhadap lembaga pendidikan Islam tersebut yang berbeda dengan Belanda.

Menyadari posisi yang menguntungkan ini, madrasah-madrasah pada era Jepang justru tumbuh subur dan berbeda secara diametral perkembangannya dengan

menjadi musuh utama Jepang, di mana Belanda yang sekian lama menindas Islam terutama di bidang pendidikan, menjadi bagian di dalamnya. Dalam hlm ini, umat Islam memandang bahwa perjuangan melawan sekutu adalah perjuangan membela rakyat dan agama. Konteks ini jelas berbeda dengan paham kalangan nasionalis, yang mendapat didikan dari Belanda.

15 Assegaf, Pendidikan, hlm.112

16 Abdullah Aly, Sejarah Pendidikan Islam di Indonesia, (Jakarta, Pustaka Setia, 1999), hlm. 110.

17 Ramayulis, Sejarah Pendidikan Islam, (Jakarta, Kalam Mulia, 2012), hlm. 343

${ }_{18}$ Menarik untuk digarisbawahi bahwa eksistensi pesantren pada masa kolonial Belanda senantiasa mengalami tekanan, sulit untuk berkembang dan berdiri sejajar dengan sekolahsekolah umum Belanda dan bahkan direndahkan. Di masa itu, pesantren mendapat pengawasan ketat melalui berbagai ordonasi yang diberlakukan oleh Belanda. Peran serta pesantren ditengah masyarakat menciut pada praktek ibadah, dakwah, sosial, dan pendidikan dan selalu dihlmangi untuk bergerak di bidang politik seiring dengan trauma Belanda bahwa pesantren kerap menjadi wadah lahirnya berbagi pemrontakan dimasa lalu. Tetapi pada perkembangan selanjutnya, pesantren memiliki peran yang lebih besar dalam pergerakan nasional. HIm ini lebih tampak pada masa penjajahan Jepang. 
kondisi sekolah-sekolah umum yang banyak ditutup oleh Jepang dan menjadi jauh berkurang jumlahnya. Seperti diakui oleh Mahmud Yunus, bahwa pada zaman pendudukan Jepang, pendidikan Islam dapat bergerak lebih bebas daripada di zaman pendudukan Belanda. ${ }^{19}$

Terkait dengan pertumbuhan madrasah ini terdapat fenomena menarik yang muncul jauh di Minangkabau sana, yaitu berdirinya madrasah Awaliyah. Sistem pengajaran madrasah ini diadakan sore hari. Dan setiap setiap hari madrasah tersebut diikuti oleh beratus-ratus anak laki-laki dan perempuan. Usia murid Madrasah Awaliyah sekitar 7 tahun. Lama proses pembelajarannya kurang lebih satu setengah jam. Materi pelajarannya ialah belajar membaca al-Quran, Ibadah, akhlak dan keimanan sebagai latihan pelajaran agama yang dilakukan di Sekolah Rakyat (SR) pagi harinya. Madrasah Awaliyah ini dikelola oleh Majelis Islam Tinggi Minangkabau. ${ }^{20}$

Kebijakan lain yang lebih fenomenal adalah pemberian pendidikan militer untuk kalangan santri. Awalnya, Jepang membentuk lembaga-lembaga pelatihan yang dimaksudkan sebagai wadah pengkaderan paramiliter beranggotakan rakyat. Wadah dimaksud antara lain: Seindojo (Panti Latihan Militer), Seinekurensho (Pusat Latihan Pemuda), Seindean (Barisan Pemuda), Keibodan (Barisan Pembantu Polisi), Peta (Pembela Tanah Air) dan juga Hizbullah yang banyak diikuti kalangan santri dan kiai. Mereka diasramakan untuk dikader dan diindoktrinisasi. ${ }^{21}$

Terkait dengan Hizbullah, ia adalah sayap militer dalam tubuh Masyumi yang didirikan pada 4 Desember 1944 atas inisiatif dari KH. Wahid Hasyim. Laskar Hizbullah pada mulanya ditujukan untuk mendidik para santri agar memiliki kemampuan militer agar bisa ikut serta dalam perjuangan bersenjata. Dalam hlm patut dibedakan, apabila PETA (Pembela Tanah Air) beranggotakan para pemuda dari kalangan non pesantren atau kalangan nasionalis, maka Hizbullah adalah wadah paramiliter santri yang secara

19 Mahmud Yunus, Sejarah Pendidikan Islam di Indonesia, (Jakarta: Mutiara Sumber Widya, 1995), hlm. 122

20 Ibid, hlm. 123

21 Dalam hlm ini perlu dijelaskan perbedaan bentuk-bentuk organisasi yang pernah didirikan dalam era pemerintahan Jepang. Djawa Hooko-Kai (Kebaktian Rakyat Jawa), dan Pusat Tenaga Rakyat (Putera) adalah organisasi sosial kemasyarakaan dengan fungsi edukatif melakukan sosialisasi program dan gagasan pemerintah Jepang dalam upaya memuluskan rencana politik. Sedangkan Seindojo (Panti Latihan Militer), Seinekurensho (Pusat Latihan Pemuda), Seindean (Barisan Pemuda), Keibodan (Barisan Pembantu Polisi), dan Peta (Pembela Tanah Air) dan Hizbullah adalah lembaga paramiliter yang mendidik dan mempersiapkan tenaga-tenaga pribumi agar memiliki kemampuan berperang. 
khusus anggotanya adalah pemuda-pemuda muslim dibawah kepemimpinan para ulama dan kyai.

Dalam konteks ini, di samping alasan perlunya mempertahankan tanah air, ada alasan yang lebih bersifat ideologis terkait berdirinya Hizbullah, yaitu doktrin yang dianut oleh para ulama bahwa berperang untuk mempertahankan agama Allah dan melawan penjajah yang dikategorikan kafir, hukumnya wajib sebagai salah satu mekanisme "Jihad Fi Sabilillah". Konteks ini mengingatkan kita pada terma klasik pembagian non-muslim dalam disiplin Figh Siyasah (Hukum Politik) Islam, bahwa orangorang non muslim yang memerangi Islam disebut sebagai Kafir Harby, yang dalam hlm ini tertuju kepada Belanda, dan Kafir Dzimmy yang dalam hlm ini ditujukan kepada Jepang. Kafir Harby adalah non muslim yang mengambil sikap memerangi umat Islam, sedangkan Kafir Dzimmy adalah non muslim yang tidak memerangi umat Islam dan bersedia hidup berdampingan dengan damai tanpa saling merugikan.

Dengan lahirnya Hizbullah ini, era pendidikan santri mengalami perubahan besar-besaran di mana mereka mendapatkan latihan militer yang spesifik demi apa yang disebut sebagai jihad fi sabilillah diatas. ${ }^{22}$ Kondisi seperti ini tak mungkin ada pada era pemerintahan Belanda yang jangankan merestui pembentukan milisi dalam tubuh umat Islam, aktivitas pendidikan saja harus selalu diawasi sebagai ancaman yang sewaktuwaktu dapat melahirkan pemberontakan. Pesantren dan ulama/kyai di zaman Belanda adalah ancaman, tetapi di zaman Jepang pesantren dan ulama adalah aset yang ingin dimanfaatkan untuk tujuan pemenangan perang. Bagi Jepang, ulama merupakan alat yang paling efektif untuk menyebarkan pengaruh dimasyarakat pedesaan. Secara cerdik orang-orang Jepang bersikap dengan Belanda dalam hlm memperlakukan umat Islam. Mereka mengakui dan berusaha untuk memanfaatkan posisi kunci kaum ulama di dalam

22 Pada mulanya, pemerintah Jepang melalui Abdul Hamid Ono, meminta Wahid Hasyim untuk mengerahkan pemuda santri masuk kedalam Heiho, sebagai tenaga serdadu cadangan Jepang yang akan dikirim ke Birma dan Kepulauan Pasifik. Namun Wahid Hasyim tidak menerima tawaran itu dengan beberapa alasan, alasan tersebut adalah sebagai berikut : (1). Latihan kemiliteran yang diberikan kepada santri lebih baik untuk pertahanan di dalam negeri. Sebab mempertahankan sejengkal tanah di dalam negeri akan lebih menggugah semangat para pemuda santri daripada bertempur dinegeri yang jauh, yan apapun alasannya tidak bisa mereka terima. (2). Pertempuran menghadapi tentara sekutu lebih baik dihadapi oleh prajurit profesional, yaitu tentara Dai Nippon sendiri. Para pemuda prajurit yang tidak profesional justru akan merepotkan tentara Jepang. 3. Menurut Wahid, jika PETA ditujukan untuk kalangan pemuda nasionalis (kalangan pemuda no-pesantren), maka sudah semestinya juga ada wadah latihan kemiliteran untuk pemuda pesantren. 
masyarakat Indonesia. Usaha-usaha untuk memanfaatkan peran para ulama untuk mempengaruhi masyarakat ini banyak dilakukan di dalam Shumubu. ${ }^{23}$

Shumubu mengadakan perjalanan keliling jawa dan mengundang konferensi kiai-kiai setempat. Sesudah Gunseikan ${ }^{24}$ mengumumkan kebijaksanaan Jepang terhadap rakyat Islam pedesaan yang akan menjadikan kiai-kiai dan guru-guru agama Islam jadi pemimpin front sipil dan bertugas menjamin keamanan dan kesiagaan rakyat. Antara Juli 1943 sampai Mei 1945 diadakan penataran para kiai selama 30 hari. Di dalam penataran ini para ulama diindoktrinasi dengan ide-ide dan propaganda Jepang. Setiap angkatan diikuti 60 orang ulama dari 20 keresidenan di Jawa. Syarat bagi peserta adalah memiliki pengaruh yang luas, perpengetahuan luas, berposisi sosial baik dan karakter yang tidak tercela. Dalam penataran ini para ulama diasramakan dan tidak boleh berhubungan dengan publik. Mereka harus hidup dalam suasana dan ideologi Jepang. ${ }^{25}$ Di sanalah dilakukan Indoktrinasi mengenai ideology politik Jepang. Diharapkan setelah dikarantina dan diberikan pendidikan selama 30 hari, faham-faham Nippon dapat tertanam dalam pemikiran ulama dan kiai dan menyebarkannya ketengah masyarakat mengingat pengaruh mereka yang sangat besar.

Kebijakan lain, dan mungkin menjadi kebijakan Jepang yang paling srategis bagi pendidikan Islam Indonesia, adalah pendirian Sekolah Tinggi Islam di Jakarta pada tanggal 8 Juli 1945 yang dipelopori oleh KH Wahid Hasyim, Kahar Muzakkar, dan Bung Hatta. ${ }^{26}$. Izin pemerintah Jepang untuk mendirikan Sekolah Tinggi ini tak lepas dari pengaruh kedekatan Masyumi, di mana $\mathrm{KH}$ Wahid Hasyim menjadi pengurus didalamnya, dengan pemerintah Jepang. Sebagaimana diketahui, Masyumi dibentuk atas restu dari pemerintah Jepang pasca bubarnya MIAI yang kerap berbenturan paham dengan Jepang sendiri. Dengan begitu, usulan-usulan yang dihadapkan pada pemerintah Jepang oleh organisasi payung Islam ini menjadi lebih mudah disetujui. ${ }^{27}$

${ }^{23}$ Benda, Bulan Sabit, hlm. 166

${ }^{24}$ Gunseikan adalah Kepala pemerintahan militer Jepang. Bisa dibandingkan dengan Gubernur Jenderal di era Pemerintahan Belanda yang mengepalai seluruh wilayah pendudukan. Saat itu dijabat oleh Hithosi Imamura.

25 Benda, Bulan Sabit, hlm, 167-170

${ }^{26}$ Zuhairini, Sejarah Pendidikan Islam, (Jakarta, Bumi Aksara, 2011), hlm. 151

${ }_{27}$ Sesungguhnya gagasan untuk mendirikan sekolah Tinggi Islam itu memiliki akar sejarah jauh ke tahun 1930-an di era penjajahan Belanda. Pada saat itu Belanda telah mendirikan Sekolah Tinggi Teknik pada 1920-an di Bandung, Sekolah Tinggi Hukum pada 1920 di Jakarta, dan Sekolah TInggi Kedokteran pada 1927 di Jakarta juga. Dan dapat diketahui siapa saja pihak yang bias menikmati keberadaan Sekolah Tinggi tersebut dengan politik diskriminasi Belanda yang hanya memperkenankan kalangan elite saja memasukinya. Dalam $\mathrm{hlm}$ ini, keinginan umat Islam untuk memeiliki perguruan tinggi yang lebih egaliter untuk sleuruh apisan masyarakat semakin bergelora. Maka dalam kongres II MIAI yang diadakan di Solo pada 2 - 7 Mei 1939 


\section{SISTEM PENDIDIKAN ZAMAN JEPANG SECARA UMUM}

Berbicara mengenai sistem pendidikan secara umum membawa kita pada pembicaraan mengenai tujuan pendidikan itu sendiri dan komponen-komponen pendukung untuk mencapai tujuan itu. Dalam hlm ini, patut diingat bahwa tak ada sistem yang dibangun tanpa tujuan.

Terkait dengan tujuan pendidikan di zaman penjajahan Jepang tidaklah banyak yang dapat diuraikan, sebab murid hanya disibukkan dengan usaha-usaha mengantisipasi peperangan sehingga perhatian dalam pendidikan yang terkait dengan visi transformasi dan modernisasi ilmu pengetahuan. Propaganada Jepang terhadap bangsa Indonesia yang mengatakan bahwa Jepang adalah "saudara tua" dan datang ke Indonesia untuk mencapai kemakmuran bersama di Asia Timur Raya adalah landasan utama pendidikan pada zaman pendudukan itu. Propaganda ini mengindikasikan bahwa segenap kerja-kerja pendidikan harus ditujukan untuk mendukung si saudara tua dalam peperangan demi kemakmuran bersama Jepang dan Indonesia. ${ }^{28}$

Oleh karena itu, elemen-elemen pendidikan yang menjauhkan bangsa Indonesia dari tujuan kemakmuran bersama itu haruslah disingkirkan termasuk penggunaan Bahasa. Penjajah Jepang mengambil kebijakan bahwa bahasa Belanda dilarang digunakan sama sekali baik di kantor-kantor maupun di sekolah-sekolah sedangkan penggunaan bahasa Jepang dinobatkan menjadi bahasa kedua. Selama masa pendudukan Jepang inilah bahasa Indonesia berkembang dan dimodernkan sehingga menjadi bahasa pergaulan dan bahasa ilmiah. ${ }^{29}$

Dalam kerangka tujuan kemakmuran bersama itu pula dapat disadari mengapa pendidikan dizaman Jepang dipenuhi dengan latihan-latihan fisik. Apa yang dimaksud sebagai kemakmuran bersama tampaknya merujuk pada kondisi-kondisi

dicantunkan agenda pembahasan mengenai perlunya dididirikan Perguruan Tinggi Islam dan kongres menyetujuinya. Lantas didirikan Pergiruan Tinggi Islam yang prtama di Solo. Tetapi Perguruan Tinggi tidak bisa berjalan sempurna karena pecahnya perang dunia 2 sehingga ditutup pada 1941. Baru pada tahun 1945 seiring dengan peluang yang diberikan oleh pemerintah Jepang, gagasan pendirian Perguruan Tinggi Islam itu mengemuka lagi dengan dipelopori oleh Masyumi. Lihat, Haidar Putra Daulay, Pendidikan Islam dalam Sistem Pendidikan Naisonal, (Jakarta, Prenada, 2014), hlm, 97-98

${ }^{28}$ Dalam istilah Jepang, rencana kemakmuran bersama itu disitilahkan sebagai Hakko I Chiu, sebuah konsep persemakmuran delapan penjuru dunia di mana Jepang sebagai pusatnya. Semboyan yang diperkenalkan Jepang pada saat itu adalah "Kemakmuran Bersama Asia untuk Asia" Menurut rencana Jepang akan menjadi pusat atas delapan wilayah persemakmuran tersebut, yaitu Manchuria, China, Muangthai, Indocina, dan Rusia. Lihat, Mudyaharja, Pengantar, hlm. 266

29 Rifa'i, Sejarah, hlm. 85 
makmur secara material yang memungkinkan terjaganya keamanan dalam wilayawilayah yang diduduki oleh Jepang. Dan terjaganya keamanan ini mensyaratkan harus siapnya masyarakat secara fisik dan pengetahuan militer untuk mengantisipasi kemungkinan perang yang bisa terjadi setiap saat.

Tak heran kemudian apabila aktivitas pendidikan di masa itu dipenuhi dengan kegiatan-kegiatan fisik semacam mengumpulkan batu dan pasir untuk kepentingan perang, membersihkan bengkel-bengkel dan asrama militer, menanam ubi-ubian dan sayur-sayuran di pekarangan sekolah untuk persediaan bahan makanan, setiap pagi wajib mengucapkan sumpah setia kepada kaisar Jepang, diberikan latihan kemiliteran, dan menanam pohon jarak untuk bahan pelumas. ${ }^{30}$

Satu hal harus dicatat di sini, bahwa pemerintah Jepang berbeda dengan Belanda dalam memperlakukan pendidikan di Indonesia. Sebagaimana umum diketahui pemerintah kolonial Belanda gemar menerapkan politik devide et impera yang menciptakan situasi konflik antar golongan. Politik ini juga digunakan dalam bidang pendidikan dengan membeda-bedakan pendidikan untuk kelas orang berada dan pendidikan untuk kelas rakyat jelata. Lebih-lebih, Belanda juga memusuhi kalangan ulama beserta segenap elemen pendidikannya semacam pesantren. ${ }^{31}$ Kebijakan Belanda sangat intimidatif terhadap lembaga pendidikan yang terakhir ini sementara disisi lain mereka mengistimewakan lembaga pendidikan sekolah yang didirikannya.

Diferensiasi pendidikan yang dilakukan pemerintah kolonial Belanda tidak dilakukan oleh pemerintah Jepang. Jepang menerapkan kebijakan penyeragaman sekolah bagi seluruh penduduk Indonesia baik dari golongan atas (bangsawan dan sejenisnya) maupun dari golongan bawah (Rakyat jelata). Mereka mempunyai kesempatan menempuh pendidikan di lembaga pendidikan yang sama. Ini merupakan perubahan paradigma yang cukup tajam dalam perubahan dunia pendidikan Indonesia

30 Lihat, Wasty Sumanto \& F.X. Soeyarno, Landasan Historis Pendidikan Indonesia, (Surabaya, Usaha Nasional, 1983), hlm, 50-51

31 Di era Belanda pendidikan sangat diskriminatif. Golongan Eropa atau yang dipersamakan dengannya mengikuti pendidikan ELS (Europese Lagere School) yakni sekolah dasar selama 7 tahun. Kemudian HBS (Hogere Burger School) yang sederajat SMU selama 5 tahun. Lalu sekolah tinggi yang lamanya disesuaikan dengan jurusannya, untuk jurusan hukum melanjutkan ke RHS selama 6 tahun, jurusan kedokteran ke GHS selama 5 tahun. Jadi rata-rata interval waktu yang dibutuhkan untuk menempuh pendidikan dasar sampai pendidikan tinggi golongan ini dibutuhkan waktu 17 sampai 18 tahun. Sedangkan untuk golongan bumiputera atau yang dipersamakan dengannya yakni yang menurut keturunan dan status sosial berasal dari bangsawan (aristokrat), pemimpin adat, ulama atau rakyat jelata mengikuti pendidikan pada jenjang dasar di HIS (Hollands Inlansche School) selama 3 sampai 5 tahun, lalu mamasuki sekolah peralihan SLO (setingkap SMP) selama 3 atau 4 tahun, seterusnya ke AMS (SMA) selama 3 tahun. Kemudian keperguruan tinggi. Lihat, Assegaf, Pendidikan, hlm. 118-119 
bila dibandingkan dengan kondisi pendidikan era Belanda yang gemar melakukan politik pecah belah (devide et empera) di mana di era Jepang politik ini diubah secara diametral dengan politik integrasi dalam pendidikan. Efek dari kebijakan ini berlanjut hingga ke masa kemerdekaan di mana semua lapisan masyarakat memiliki hak dan kesempatan yang sama untuk mendapatkan pendidikan, sebagaimana hal itu telah menjadi keinginan rakyat sejak lama sebagai suatu aspirasi umum yang sangat sulit dicapai pada era pemerintahan Belanda sebelumnya.

Sebagaimana telah dikemukakan, pada era pemerintahan Jepang semua sekolah warisan Belanda yang jenisnya bermacam-macam itu ditutup. Jepang lantas memperkenalkan sebuah sistem pendidikan baru yang lebih bersifat integratif dan egaliter di mana rakyat tak lagi dibeda-bedakan berdasar kelas sosial tertentu.. Jepang membagi sistem persekolahn menjadi tiga tingkatan yaitu; (1) Pendidikan dasar selama 6 tahun, (2) Pendidikan Menegah selama 6 tahun, dan (3) Pendidikan tinggi. ${ }^{32}$ Pada lama masa tempuh pendidikan dasar dan menengah inilah kebijakan Jepang juga memiliki pengaruh yang bertahan lama hingga sekarang.

Walaupun di satu sisi kebijakan pendidikan oleh pemerintah Jepang ini ada aspek positifnya karena penyeragaman sekolah, namun disisi lain, jika dilihat pada dinamika pendidikan secara umum, ternyata juga membawa pengaruh negatif, terutama dilihat dari jumlah sekolah yang menjadi jauh lebih sedikit dari era penjajahan Belanda. Sekolah Dasar menurun jumlahnya dari 21.500 menjadi 13.500, Sekolah. Sekola Lanjutan menurun dari 850 menjadi 20, begitu pula jumlah murid sekolah dasar menurun sebanyak $30 \%$ dan murid sekolah menengah merosot $90 \%$. Jumlah guru sekolah dasar menurun $35 \%$ dan guru sekolah menengah merosot $95 \% .{ }^{33}$ Penyebabnya antara lain adalah beratnya tugas sebagai guru terutama disebabkan berubahnya Bahasa pengantar yang digunakan. ${ }^{34}$ Legipula, tekad Jepang untuk menghabisi apapun yang tersisa sebagai warisan pendidikan Belanda, membuat mereka mengambil kebijakan ekstrem yang di satu sisi merugikan berupa penurunan drastis jumlah sekolah.

Pada tingkat praktek, kebijakan tersebut pada awalnya mengalami kesulitan di segmen kemampuan verbal tenaga pengajarnya. Kesulitan ini berpangkal pada

32 Lihat, Redja Mudyaharja, Pengantar Pendidikan, Sebuah Studi Awal tentang Dasar-Dasar Penidikan pada Umumnya dan Pendidikan Indonesia, (Jakarta, Rajawali Press, 2001), hlm, 269270

33 Departemen Pendidikan dan Kebudayaan, Pendidikan, hlm. 139

34 Mudyaharja, Pengantar, hlm. 272 
kebijakan pelarangan bahasa Belanda dan bahasa-bahasa lain selain bahasa Jepang dan Indonesia yang selama ini digunakan. ${ }^{35}$

Hal tersebut telah menjadi sebab menurunnya jumlah tenaga guru. Guruguru banyak yang tidak mampu menyampaikan materi yang berubah sangat berat. Perubahan bahasa pengantar yang digunakan menjadi kendala yang tidak mudah. Jika pada masa penjajahan kolonial Belanda, diijinkan penggunaan bahasa daerah dalam proses belajar mengajar, maka pada era penjajahan Jepang semua penggunakan bahasa selain Indonesia dan bahasa Jepang dilarang.

Menggarisbawahi kondisi diatas, menurut Djohan Makmur terjadinya penurunan jumlah sekolah, murid, dan guru di era pemerintahan Jepang disebabkan karena pada awalnya Jepang memiliki beberapa kesulitan yang perlu diatasi, terutama masalah guru. Pemerintah kolonial sebelumnya, Belanda, tidak pernah sejak awal mempersiapkan secara khusus guru-guru bumiputera untuk mengajar di sekolahsekolah menengah, apalagi sekolah menengah atas. Maka pada saat Jepang memberlakukan kebijakan pendidikannya yang membebaskan, wajar bila tenaga guru untuk tingkatan sekolah dimaksud menjadi langka. Padahlm, minat masyarakat untuk memsukinya justru membludak. Kesulitan lainnya ialah mengenai buku-buku pelajaran. Semua buku pelajaran ditulis dalam bahasa Belanda, sementara pemerintah pendudukan Jepang melarang pemakaiannya. ${ }^{36}$

Sedangkan dalam kerangka pembinaan siswa di sekolah, Jepang mengharuskan beberapa kegiatan seremonial rutin yang antara lain ; setiap pagi mengibarkan bendera kebangsaan Jepang, menyanyikan lagu kebangsaan Jepang, menghormat kepada istana Kaisar Jepang (Tenno Heika), mengucapkan sumpah setia kepada cita-cita Indonesia dalam rangka program Asia Timur Raya, melakukan kerja bakti dan mengumpulkan bahan-bahan untuk kepentingan keperluan militer, melakukan senam dan latihan fisik. ${ }^{37}$ Di samping itu, sebagaimana dikemukakan dimuka, para siswa juga dilarang menggunakan bahasa selain bahasa Indonesia dan Jepang dalam sekolah. Kita bisa menyebut bahwa kegiatan-kegiatan seremonial diatas adalah cara Jepang untuk mengindoktrinasi bangsa Indonesia tentang budaya mereka. Tetapi jika melirik pada sejarah, seungguhnya Belanda juga melalkyukan hlm serupa pada lembaga

\footnotetext{
35 Lihat, Assegaf, Pendidikan, hlm. 125

36 Lihat, Djohan Makmur, Sejarah Pendidikan di Indonesia Zaman penjajahan. (Jakarta:Depdikbud, 1993), hlm. 100-101

37 Lihat, Mudyaharja, Pengantar, hlm. 271
} 
pendidikannya dengan mempopulerkan budaya Barat dalam proses belajarmengajarnya.

\section{PENGARUH POLITIK PENDIDIKAN JEPANG TERHADAP PENDIDIKAN ISLAM}

Sebagaimana ditegaskan dimuka, bahwa pada saat pertama kali datang ke Indonesia, Jepang berusaha untuk meraih simpati umat Islam lewat berbagai pendekatan politik. Keputusan Jepang untuk membubarkan MIAI yang kerap berseberangan dengan Jepang disatu sisi merugikan umat Islam, tetapi disisi lain menguntungkan karena hadirnya Masyumi sebagai penggantinya memiliki kedekatan dengan pemerintah Jepang. Kedekatan mana sangat efektif digunakan oleh umat Islam dalam memuluskan rencana pembangunan kehidupan Islam yang bisa lebih mudah disetujui oleh pemerintah Jepang. Salah satunya adalah gagasan pendirian Sekolah Tinggi Islam sebagaimana disampaikan dimuka. Sekolah tinggi pertama ini memiliki pengaruh jangka panjang dalam dinamika pendidikan tinggi Islam di Indonesia untuk melahirkan para sarjana muslim yang menguasai pengetahuan keagamaan dengan standard akademis, selain menjadi cikal bakal bagi lahirnya perguruan Tinggi Islam yang akan lahir kelak kemudian hari pada era kemerdekaan.

Melalui Masyumi pula sebuah proses pendidkan berbeda lahir dalam tubuh umat Islam yaitu pada saat terbentuknya laskar Hizbullah. Di titik ini, pendidikan para santri mengalami perubahan yang bahkan belum pernah dikenal sebelumnya, yaitu pendidikan militer secara spesifik. Di era Belanda, membentuk paramiliter yang terdiri dari pemuda-pemuda muslim sangat jauh dari kemungkinan direstui mengingat kebijakan Belanda yang selalu menekan pendidikan Islam seiring dengan ketakutan laten mereka bahwa dari rahim pendidikan Islam pemberontakan terhadap pemerintah kolonial acapkali lahir dan mengobarkan semangat perjuangan rakyat untuk mengusir mereka dari Indonesia. Lembaga yang paling tertuding dalam hal ini jelas pesantren. Tetapi Jepang tak meneruskan politik kebencian itu, alih-alih, mereka malah memberikan ruang yang lega bagi umat Islam untuk mengikutsertakan para santri dalam pelatihan militer terlembaga yang semula dimaksudkan agar hasilnya kelak bisa membantu Jepang sendiri dalam peperangan, yang kemudian ternyata pada perjalanan selanjutnya justru sangat fungsional untuk mempertahankan tanahairnya.

Kendatipun di era Belanda para kyai bersama dengan santri telah biasa menggelorakan perlawanan kepada pemerintah Belanda, namun perlawanan tersebut 
dilakukan tidak dengan prinsip-prinsip militer yang terarah, malainkan melalui perlawanan dengan strategi yang acak berbekal arahan dan kepemimpinan dari para kyai dan dilakukan semata demi semangat jihad fi sabilillah. Saat Hizbullah terbentuk, pengetahuan berjuang para santri dibangun secara lebih sistematis karena mendapat bimbingan langsung dari pemerintahan Jepang dengan berkeinginan memiliki milisi dari kalangan rakyat yang akan mendukungnya dalam peperangan. Melalui kebijakan ini, kelas santri mendapatkan ruang peranan baru dalam keikutsertaannya dalam pergerakan nasional, yaitu santri yang terlatih untuk berperang dengan penggunaan senjata modern dan strategi perang yang lebih sistematis, kendatipun dalam hlm ini tak setingkat dengan militer sesungguhnya.

Di titik inilah kehadiran Jepang di Indonesia telah menanamkan jiwa "pemberani" pada bangsa Indonesia, utamanya umat Islam, lewat berbagai pelatihan fisik yang dirutinkan setiap hari sebagai bagian aktivitas pendidikan, dan yang dimaksudkan sebagai latihan kesiapan bertempur. Lebih-lebih saat didirikannya beberapa organisasi perjuangan rakyat yang memberikan pendidikan militer strategis semacam Hizbullah diatas.

Kebijakan pelarangan memakai Belanda serta kewajiban memakai bahasa Indonesia dan Jepang di sekolah, juga memberikan dampak positif. bagi perkembangan pendidikan Islam di Indonesia, mengingat kewajiban ini juga diharuskan di dalam lembaga pendidikan Islam modern semacam madrasah. Pemakaian bahasa Indonesia menjadi lebih memasyarakat tatkala guru-guru yang mengajar di sekolah dan madrasah setiap harinya diwajibkan untuk memakai bahasa itu. Akibat pelaksanaan kebijakan ini, penduduk yang tinggal di daerah pedesaan -rata-rata muslim- yang sebelumnya tidak mengenal bahasa Indonesia menjadi lebih mengenal bahasa negerinya sendiri.

Efek lain dari kebijakan bahasa ini adalah lahirnya semangat nasionalisme yang lebih dalam dan merata. Masyarakat desa dan masyarakat kecil kota yang sejak awal tidak mendapatkan pendidikan sekolah ala Belanda, memiliki peluang untuk meningkatkan diri dalam kemampuan penggunaan bahasa Indonesia. Mereka bersemangat mempelajari bahasa Indonesia, yang harus mereka pahami sejak dari sekolah rendah sampai sekolah menengah. ${ }^{38}$ Dalam hlm ini, kebijakan Jepang malah menjadi elemen pemersatu, utamanya dalam aspek pendidikan bangsa.

${ }^{38}$ Agus Salim, Indonesia Belajarlah! Membangun Pendidikan Indonesia, (Yogyakarta: Tiara Wacana, 2007), hlm. 213 
Berbeda dengan pemerintah kolonial Belanda yang justru melahirkan situasi konflik dalam kebijakan pendidikannya dengan menekan lembaga pendidikan Islam semisal pesantren, Jepang malah merangkul elemen utama pendidikan Islam ini kedalam kebijakan pemerintahannya untuk bahu membahu mencapai apa yang disebut Jepang sebagai tujuan kemakmuran bersama. Ini terbukti dengan intensifnya pemerintah Jepang berkunjung ke pesantren-pesantren besar, meskipun secara politis, kunjungan itu bisa juga ditafsirkan sebagai usaha Jepang dalam mengawasi pesantren dan melakukan kontrol kendatipun secara lebih lunak dan persuasif. Ini diupayakan agar tidak lahir sentiment agama persis seperti disematkan terhadap Belanda yang dituding kafir karena menekan Islam, dan patut untuk diperangi sebagai perlawanan suci jihad fi sabilillah. Dalam hlm ini, menekan pesantren sebagai lembaga pendidikan yang mengajarkan nilai-nilai Islam, dipersepsikan sama dengan menekan Islam itu sendiri sebagai sebuah agama.

Di sisi lain, politik penyeragaman pendidikan juga melahirkan pengaruh yang tak kecil artinya bagi pendidikan Islam di Indonesia. Sementara lembaga-lembaga pendidikan warisan Belanda ditutup oleh Jepang untuk diganti dengan pendidikan umum yang seragam, tetapi lembaga pendidikan Islam semacam pesantren dan madrasah dikecualikan dengan kebijakan yang tidak mengusik keberadaannya. Dalam hlm ini, Jepang memandang bahwa pesantren dan madrasah adalah lembaga pendidkan asli yang bukan merupakan warisan penjajah. Lebih-lebih bila mengingat bahwa Jepang ingin menarik simpati umat Islam Indonesia agar mendukung mereka dalam perjuangan memenangkan perang Asia Timur Raya.

Jika harus dibandingkan, pesantren sebagai lembaga pendidikan Islam jalur pendidikan luar sekolah yang diselenggarakan oleh masyarakat, eksistensinya pada masa kolonial Belanda sdnantiasa mengalami tekanan, tidak dapat tumbuh tegak apalagi berdiri sejajar dengan sekolah-sekolah umum Belanda, bahkan eksistensinya direndahkan dengan sekian banyak ordonansi yang memasung geraklangkahnya pada aktivitas sosial lebih luas. Pesantren selalu mendapat pengawasan ketat seiring kecurigaan Belanda bahwa lembaga ini kerap menjadi rahim lahirnya pemberontakan. Aktivitas pesantren pada masa Belanda dipasung dalam ruang praktek-praktek ibadah, dakwah, sosial, dan pendidikan. HIm ini berbeda dengan eksistensinya di era pemerintahan Jepang di mana pihak pesantren dapat ikut serta berperan aktif dalam politik dan pergerakan nasional. Di masa inilah pesantren bersama para santrinya bisa menunjukkan peranannya secara lebih maksimal dalam upaya-upaya menuju kemerdekaan. 
Tetapi tetap saja terdapat aspek negatif dari kebijakan Jepang. Kedatangan Jepang jelas bertujuan imperialis untuk menguras kekayaan Indonesia. Jepang menindas penduduk pribumi dengan sistem kerja paksa (romusa). Sebagian dari tujuan pendidikan pada zaman penjajahan jepang ialah untuk memenuhi tanaga cuma-cuma (romusha) dan memproduksi prajurit-prajurit untuk membantu peperangan bagi kepentingan Jepang. Oleh karena itu pelajar-pelajar diharuskan mengikuti latihan fisik, latihan kemilitran dan indoktrinasi. ${ }^{39}$ Dan setiap saat, selalu ada kemungkinan ancaman hukuman mati bagi yang menentang kebijakan Jepang, di mana di era Belanda hanya menerapkan hukuman penjara dan pembuangan.

Kebijakan pemerintah Jepang yang terlalu berlebihan dalam memerintahkan penghormatan terhadap kaisar Jepang juga bukan merupakan kebijakan populis yang disukai oleh umat Islam. Bagaimanapun, cara menghormat dengan membungkukkan badan kepada istana kaisar seperti yang dipraktekkan dalam sikap Sei Kerei dinilai melukai keyakinan teologis umat Islam yang hanya memperkenankan sikap serupa ditujukan kepada Tuhan dalam sholat. Selain itu, kebijakan Jepang agar supaya guruguru mengajarkan dan menanamkan budaya Jepang dalam aktivitas pendidikannya sebagai kewajiban rutin juga dinilai sebagai upaya untuk mengasingkan anak didik dari akar budayanya sendiri, budaya Indonesia. Dua kebijakan tersebut telah menimbulkan sikap resisten dan penolakan kalangan Islam untuk melaksanakannya sesuai dengan perintah Jepang.

Pada saat Indonesia merdeka, dalam usaha untuk menghapus sisa-sisa indoktrinasi budaya Jepang dalam aktivitas pendidikan nasional, Menteri Pendidikan Pengajaran dan Kebudayaan pertama Indonesia, yang waktu itu dijabat oleh Ki Hajar Dewantara, mengeluarkan instruksi umum kepada semua lembaga pendidikan yang intinya memerintahkan kepala sekolah dan guru agar (1). Mengibarkan Sang Merah Putih setiap hari di hlmaman sekolah sebagai ganti dari mengibarkan bendera Jepang, (2), Menyanyikan lagu kebangsaan Indonesia Raya sebagai ganti dari menyanyikan lagu kebangsaan Jepang (Kimigayo), (3), Menghapus bahasa dan upacara yang berasal dari Jepang, (4), Memberikan semangat kebangsaan kepada murid. ${ }^{40}$

39 Departemen Pendidikan dan Kebudayaan, Pendidikan, hlm. 138

40 Lihat, Samsul Nizar, Sejarah Pendidikan Islam.( Jakarta: Kencana, 2010), hlm. 346. 


\section{PENUTUP}

Adalah kebohongan apabila buku-buku sejarah pendikan Indonesia hanya menegaskan bahwa situasi pendidikan zaman Jepang secara umum sangat mundur dan degradatif. Orang mungkin hanya melirik efek politik, ekonomi, dan budaya terhadap kebijakan mereka di mana kehidupan masyarakat sangat tertekan secara ekonomis, ketakutan secara politis oleh hukuman mati yang bisa dating setiap saat, dan kebimbangan ideologis kultural akibat indoktrinasi Nippon.

Jumlah lembaga pendidikan memang menurun drastis di masa Jepang, namun penurunan jumlah itu diiirngi dengan perbaikan sistem yang lebih egaliter dan tidak diskriminatif. Dalam hlm ini orang harus mengingat prinsip bahwa tak ada satu kebijakan politiik-pun yang tak memiliki ekses positif dan negatif saat ia diberlakukan di tengah-tengah masyarakat. Jika kebijakan pendidikan pemerintah Jepang tampak secara umum merugikan bagi sekolah-sekolah warisan Belanda, tidak demikian hlmnya dengan kebijakan terhadap lembaga pendidikan Islam.

Pada dasarnya, usaha pemerintah Jepang pada awal masa penjajahannya dalam mendekati Islam telah memberikan keuntungan bagi umat Islam untuk mengembangkan lembaga pendidikannya. Keuntungan itu berupa lebih tersedianya ruang lega bagi pendidikan Islam -semacam pesantren dan madrasah- untuk bergerak dan mengembangkan diri daripada pada masa penjajahan Belanda.

Orang mungkin masih bisa memberi alasan bahwa kebijakan yang lebih mendukung Islam itu dilandasi oleh motif ingin mengambil simpati agar umat Islam berpihak kepada Jepang dalam perang menghadapi tentara sekutu. Tetapi bagaimanapun, lepas dari kecurigaan adanya motif tertentu tersebut, sejarah berbicara bahwa kondisi pendidikan Islam masih jauh lebih baik dan bahkan berkembang dengan leluasa dibanding kondisinya di zaman Belanda.

\section{DAFTAR PUSTAKA}

Ali, Fachry \& Bahtiar Effendy, (1986), Merambah Jalan Baru Islam, (Bandung, Mizan) Aly, Abdullah, (1999), Sejarah Pendidikan Islam di Indonesia, (Jakarta, Pustaka Setia) 
Assegaf, Abdurrahman, (2007), Pendidikan Islam di Indonesia, (Yogyakarta, Sunan Kalijaga Press)

Benda, Harry J., (1980), Bulan Sabit dan Matahari Terbit : Islam Indonesia pada Masa Pejajajahan Jepang, (Jakarta, Pustaka Jaya)

Daulay, Haidar Putra, (2014), Pendidikan Islam dalam Sistem Pendidikan Nasional, (Jakarta, Prenada)

Departemen Pendidikan dan Kebudayaan, (1973), Pendidikan Indonesia dari Jaman ke Jaman, (Jakarta, Balai Pustaka).

Djaelani, Abdul Qadir, (2016), Sejarah Gerakan Politik Umat Islam Indonesia, (Jakarta, Bee Media)

Gunawan, Ary. H,. (1995), Kebijakan-kebijakan Pendidikan, ( Jakarta, Rineka Cipta)

Hidayat, Komaruddin \& Hendro Prasetyo, (2000), IAIN Problem dan Prospek, (Jakarta, Departemen Agama Republik Indonesia)

Makmur, Djohan, (1993), Sejarah Pendidikan di Indonesia Zaman penjajahan. (Jakarta:Depdikbud, 1993)

Mudyaharja, Redja, (2001), Pengantar Pendidikan, Sebuah Studi Awal tentang DasarDasar Penidikan pada Umumnya dan Pendidikan Indonesia, (Jakarta, Rajawali Press)

Nizar, Syamsul, (2010)Sejarah Pendidikan Islam.( Jakarta: Kencana, 2010), hlm. 346.

Porbakawatja, Soegarda, (1970) Pendidikan dalam Alam Indonesia Merdeka, (Jakarta, Gunung Agung)

Pringle, Robert, (2018), Islam Ditengah Kebhinnekaan, Memahami Islam dan Politik di Indonesia, (Jakarta, Prenada)

Rickfles, M.C, (2004), Sejarah Indonesia Modern, (Jakarta, Serambi)

Rifa'i, Muhammad, (2011), Sejarah Pendidikan Nasional, (Yogyakarta: Ar-Ruzz Media)

Salim, Agus, (2007), Indonesia Belajarlah! Membangun Pendidikan Indonesia, (Yogyakarta: Tiara Wacana)

Sumanto, Wasty \& F.X. Soeyatno, Landasan Historis Pendidikan Indonesia, (Surabaya, Usaha Nasional, 1983), hlm, 50-51

Suminto, Aqib, (1984), Politik Islam Hindia Belanda, (Jakarta, LP3ES)

Syarif, M., (2019), Politik Etis Pemerintah Hindia Belanda dan Pengaruhnya Terhadap Pesantren, Inovatif Jurnal Penelitian Pendidikan, Agama dan Kebudayaan, Volume 5 Nomor 1 (Pebruari 2019)

Tilaar, H.A.R.. (1999). Pendidikan, Kebudayaan, dan Masyarakat Madani Indonesia: Strategi Reformasi Pendidikan Nasional, (Bandung: Remaja Rosda Karya)

Van Veer, Paul, (1986), Perang Aceh, Kisah Kegagagalan Snouck Hurgronje, (Jakarta, Grafiti Pers)

Yunus, Mahmud, (1962), Sejarah Pendidikan Islam di Indonesia, (Jakarta, Mutiara Sumber Widya)

Zuhairini, (2014), Sejarah Pendidikan Islam, (Jakarta, Bumi Aksara, 2011) 